UDC 332; DOI 10.18551/rjoas.2022-01.11

\title{
ANALYSIS OF THE BALANCE OF SUPPLY AND DEMAND FOR CURLY RED CHILI IN MAGELANG REGENCY, CENTRAL JAVA PROVINCE, INDONESIA
}

\author{
Astuti Eka Puji ${ }^{\star}$ Ekowati Titik, Florentina Kusmiyati \\ Master's Study Program of Agribusiness, Faculty of Animal Science and Agriculture, \\ University of Diponegoro, Indonesia \\ *E-mail: eka isti@yahoo.co.id
}

\begin{abstract}
This study was aimed to analyze the effect of production costs, harvested area and producer-level curly chili prices on the supply of curly red chilies; analyze the influence of the price of curly chili at the consumer level, the price of other goods (large red chili) and consumer income on the demand for curly red chili; analyze the elasticity of supply and demand for curly red chili; and analyze the balance of supply and demand for curly red chili in Magelang Regency. Determination of the number of respondents curly red chili farmers at the sub-district and village levels using a quota sampling of 135 people. Sampling of the final consumer by accidental sampling amounted to 50 people. Data analysis for supply and demand with multiple linear regression techniques. The results showed that (1) the variables of production costs, land area, and producer level prices had a significant effect on the supply of curly red chili. Price variables at the consumer level, and income have a significant effect on the demand for curly red chili, while the price variables for other goods have no significant effect on the demand for curly red chili. (2) The results of the elasticity of supply consist of the elasticity of production costs showing that it is elastic, the elasticity of harvested area shows that it is inelastic and the price elasticity of curly red chili at the producer level is inelastic. The result of the elasticity of demand which consists of the price elasticity of curly red chili at the consumer level is inelastic, the price elasticity of other goods (large red chili) is elastic and the elasticity of consumer income is inelastic. (3) The balance of supply and demand is $b=-2.67<1$, it can be concluded that the effect of price on supply and demand for curly red chili in Magelang Regency is convergent or close to the equilibrium point.
\end{abstract}

\section{KEY WORDS}

Curly red chili, cobweb, supply and demand.

Horticultural commodities are potential commodities that have high economic value and have the potential to continue to be developed. One of the horticultural commodities that have the potential to be developed is chili. Curly red chili (Capsicum annuum L.) is one of the commodities that has a high enough economic value, because of its large enough role to meet domestic needs as an export commodity and food industry (Wahyudi and Soepartini, 2018).

The growth of curly red chili is influenced by the very high consumer needs. The increase in the amount of curly red chili production on offer is also influenced by many things, such as the price of curly red chili at the producer level, the cost of production, and the area of harvest. The production of curly red chili is very volatile this indicates that the elasticity of the supply and demand of chili peppers is also fluctuating, as is the theory of supply that the small size of the supply is determined by the number of goods produced.

Magelang Regency is one of the centers for curly red chili production in Central Java since 2018 experiencing a surplus of 24,642 tons of curly red chili per year or 67.46 tons per day and partnering with supermarkets since 2012. Red chili production in Magelang Regency contributes $10-11 \%$ of chili production in Central Java or $1.5-2.0 \%$ of total production nationally, the average productivity of curly red chili in Magelang Regency varies, namely 5.6-6.5 tons/ha, with a total The largest production is in the Subdistricts of Pakis, Dukun and Srumbung, this is what underlies the research conducted in Magelang Regency. 
The increase in the amount of curly red chili production is in line with the increase in the harvested area of curly red chili, the amount of curly red chili production offered from year to year is relatively fluctuating. The production of curly red chili has increased from 2015 amounting to 24,190 tons and in 2016 to 26,000 tons. This is in accordance with the level of consumption of household needs and the increasing industrial needs that continue to increase. The amount of curly red chili production in 2017 decreased to 25,630 tons and in 2018 it decreased again to 21,076 tons. Total production in 2019 decreased by 10,426 tons, in 2020 it increased to 16,086 tons. The decline in production is due to the influence of weather, climate and pests, while the harvested area increases every year (Statistics Center Magelang Regency, 2017).

The harvested area of curly red chili in Magelang Regency in 2014 was 3,855 ha, increasing in 2017 to $4,707 \mathrm{ha}$. The decline in harvested area occurred in 2018 to $3,756 \mathrm{Ha}$. In 2019 there was a decrease in harvested area of 3,295 $\mathrm{Ha}$ and in 2020 there was an increase of 3,582 $\mathrm{Ha}$. This decline was due to many factors, one of which was the shift in land use to other food and horticultural commodities (Statistics Center Magelang Regency, 2017).

The demand for curly red chili continues to increase from 2009 to 2017, based on data from the Food Security Service of Central Java Province, the average development of demand for curly red chili in Magelang Regency is $8.97 \%$ per year. It is estimated that domestic and international market demand for horticultural commodities in the future will not only come from the increase in population and income levels but also consumption per capita. Along with the growing growth and development of the national economy, the demand from the processing industry and the food industry is also getting higher (Chairia, 2013).

The consumption rate of curly red chili in Magelang Regency in 2019 was 3,970 tons/year, with domestic use of 2,738 tons/year and for the processing and restaurant/catering industries of 1,232 tons/year, with a higher consumption of red chili than cayenne pepper with a ratio of 60: 40 percent. The type of curly red chili that is more widely used by the community and industry, because it prefers the taste, level of spiciness and color found in curly red chili (Food Security Agency, 2019).

Consumers basically want the price of curly red chili to go down, while producers want the price of curly red chili to go up. When these two sides are brought together, a midpoint is obtained which is called the equilibrium point. The balance between supply and demand usually lies in price. Equilibrium price or price equilibrium is a price formation that occurs at the meeting point of the supply and demand curves. If this price balance is reached, it will be used as a benchmark for determining the price, therefore the price balance is where the price at the consumer and producer level together does not want to increase or decrease the amount of consumption and the amount of production (Rahardja and Manurung, 2006).

\section{METHODS OF RESEARCH}

The research method used is the survey method. The research was carried out in MayJune 2020. The locations were carried out in 3 sub-districts based on the order of the largest number of curly red chili production in Magelang Regency, namely Pakis, Dukun, and Srumbung Districts.

Determination of the sample location of the study using multistage sampling, namely this type of sampling technique is carried out at 2 levels of sub-district and village. The number of sub-districts taken is three sub-districts, namely Pakis, Dukun, and Srumbung sub-districts. Then three villages were taken from each sub-district. Determination of the number of respondents' curly red chili farmers using a sampling quota, with a total of 135 people. Each selected village was then taken 15 people with the criteria of being the village that has the highest amount of red chili production based on Statistics Center data in 2018. The final consumer data collection method using accidental sampling was carried out in 3 markets, namely Rejosari Market (Pakis District), Talun Market (Dukun District) and 
Srumbung Market. The technique of determining the sample by accident, the researcher took a sample that was encountered during the study with a sample of 50 people.

The method of data analysis is quantitative analysis. Quantitative data analysis was used to analyze the factors that influence supply and demand, elasticity of supply and demand for curly red chili and the balance of supply and demand for curly red chili in Magelang Regency.

Analyzing the effect of variable production costs, harvested area of curly red chili, producer level price of curly red chili on the supply of curly red chili, using multiple linear regression analysis, the equation is as follows:

$$
Y_{1}=a+b_{1} X_{1}+b_{2} X_{2}+b_{3} X_{3}+e
$$

Where:

$\mathrm{Y}_{1}=$ Supply of curly red chili $(\mathrm{kg} / \mathrm{month})$;

$\mathrm{a}=$ Constant that is the value of $\mathrm{Y}$ if $\mathrm{X} 1, \mathrm{X} 2, \mathrm{X} 3$;

$\mathrm{b}_{1}, \mathrm{~b}_{2}, \mathrm{~b}_{3}=$ Regression coefficient;

$\mathrm{X}_{1}=$ Production cost (IDR);

$\mathrm{X}_{2}=$ Harvested area of curly red chili (ha);

$\mathrm{X}_{3}=$ Price of curly red chili at the producer level (IDR/kg);

e = Error value.

Mathematically, analyze the effect of the variable price of curly red chili at the consumer level, the price of other goods (large red chili), and consumer income on demand for curly red chili. The demand for curly red chili is formulated as follows:

$$
Y_{2}=a+b_{1} X_{1}+b_{2} X_{2}+b_{3} X_{3}+e
$$

Where:

$\mathrm{Y}_{2}=$ Demand for curly red chili ( $\left.\mathrm{kg} / \mathrm{month}\right)$;

$\mathrm{a}=$ Constant;

$b_{1}, b_{2}, b_{3}=$ Regression Coefficient;

$\mathrm{X}_{1}=$ Price of curly red chili at consumer level (IDR/kg);

$\mathrm{X}_{2}=$ Consumer income (IDR);

$\mathrm{X}_{3}=$ Price of other goods (large red chili) (IDR/kg);

e = Error value.

Analyzing the elasticity of supply of curly red chili. The elasticity of supply analyzes the level of the quantity supplied to changes in the variables that influence it:

- Production Cost Elasticity:

$$
\begin{aligned}
& \mathrm{EL}=\frac{\% \text { change in supply of curly red chili }\left(\mathrm{Y}_{1}\right)}{\% \text { change in production costs }\left(\mathrm{X}_{1}\right)} \\
& \mathrm{b} 1 \times \underline{\mathrm{Y}}_{1}
\end{aligned}
$$

The elasticity of supply on production costs, the variable that causes changes in the quantity supplied is the production cost of curly red chili.

- Elasticity of Harvested Area:

$$
\begin{aligned}
& \text { Eptp }=\frac{\% \text { change in supply of curly red chili }\left(\mathrm{Y}_{1}\right)}{\% \text { change in Harvest Area }\left(\mathrm{X}_{2}\right)} \\
& \text { b2 } \times \underline{\mathrm{X}}_{2}
\end{aligned}
$$

The elasticity of supply on the harvested area, the variable that causes changes in the quantity supplied is the harvested area of curly red chili itself. 
- Price elasticity of Producer Level:

$$
\text { EbiP }=\frac{\text { curly red chilies } \% \text { change in supply of curly red chilies }\left(\mathrm{Y}_{1}\right)}{\% \text { change in the price of curly red chili }\left(\mathrm{X}_{3}\right)}
$$

The elasticity of supply on the price of curly red chili at the producer level, the variable that causes changes in the quantity supplied is the price of curly red chili at the producer level, next is to calculate the elasticity of demand for curly red chili. This demand elasticity analyzes the level of the number of requests to changes in the influential variables.

- Price Elasticity of Demand:

$$
\begin{aligned}
& \text { Eptk }=\frac{\% \text { change in demand for curly red chili }\left(\mathrm{Y}_{2}\right)}{\% \text { change in price of curly red chili }\left(\mathrm{X}_{1}\right)} \\
& \mathrm{b} 1 \times \underline{\mathrm{Y}}_{1}
\end{aligned}
$$

The price elasticity of demand, the variable that causes changes in the quantity supplied is the price of curly red chili at the consumer level.

- Income Elasticity of Consumers:

$$
\begin{aligned}
& \mathrm{EJt}=\frac{\% \text { change in demand for curly red chili }\left(\mathrm{Y}_{2}\right)}{\% \text { change in consumer income }\left(\mathrm{X}_{2}\right)} \\
& \mathrm{b} 2 \times \frac{\mathrm{X} 3}{Q}
\end{aligned}
$$

The elasticity of demand on consumer income, the variable that causes a change in the quantity supplied is the total income of the final consumer.

- Cross Elasticity:

$$
\begin{aligned}
& \mathrm{Ex}=\frac{\% \text { change in demand for curly red chili(Q) }}{\% \text { change in price for big red chili (Ps) }} \\
& \mathrm{b} 3 \times \frac{\mathrm{Ps}}{Q}
\end{aligned}
$$

Cross elasticity occurs because it is influenced by the price of other goods, namely curly red chilies, namely large red chilies. This causes a change in the quantity demanded.

The following are the criteria for the elasticity of supply and demand are:

- $E<1$; inelastic, which means that every 1 percent change in the independent variable $X$ will result in a change in the supply/demand of curly red chilies of less than 1 percent;

- $E=1$; unitary, which means that every 1 percent change in the independent variable $X$ will result in a 1 percent change in the supply/demand of curly red chilies;

- $E>1$; elastic, which means that every 1 percent change in the independent variable $X$ will result in a change in the supply/demand of red chilies by more than 1 percent.

Analyzing the balance of supply and demand for curly red chili using the model Cobweb with the supply and demand functions being influenced by price factors.

\section{RESULTS AND DISCUSSION}

The number of curly red chili farmers in this study were 135 farmers drawn from three sub-districts, namely Pakis, Dukun, and Srumbung sub-districts. and 50 final consumers from 3 markets, namely Rejosari Market (Pakis District), Talun Market (Dukun District) and Srumbung Market (Srumbung District). 
Table 1 - Characteristics of Curly Red Chili Farmers

\begin{tabular}{|c|c|c|}
\hline Information & Number of people & Percentage, \% \\
\hline \multicolumn{3}{|c|}{ Age (Year) } \\
\hline $20-30$ & 12 & 9 \\
\hline $31-40$ & 33 & 24 \\
\hline $41-50$ & 47 & 35 \\
\hline $51-60$ & 31 & 23 \\
\hline$\geq 61$ & 12 & 9 \\
\hline Total & 135 & 100 \\
\hline \multicolumn{3}{|c|}{ Education } \\
\hline Elementary & 63 & 47 \\
\hline SMP & 42 & 31 \\
\hline SMA & 25 & 18 \\
\hline Universities & 5 & 4 \\
\hline Total & 135 & 100 \\
\hline \multicolumn{3}{|c|}{ Gender } \\
\hline Male & 135 & 100 \\
\hline Female & 0 & 0 \\
\hline Total & 135 & 100 \\
\hline \multicolumn{3}{|c|}{ Farming duration(year) } \\
\hline$<10$ & 49 & 36 \\
\hline $11-20$ & 84 & 62 \\
\hline$>21$ & 2 & 2 \\
\hline Total & 135 & 100 \\
\hline
\end{tabular}

Respondents of curly red chili farmers in Magelang Regency have an average age of 45.4 years, the most of which are ages ranging from $41-50$ years, namely 47 people or $35 \%$, and the few respondents aged 61 years as many as 12 people or $9 \%$.

Most of the farmers in Pakis, Dukun, and Srumbung sub-districts have an elementary education (elementary school), 63 people (47\%), and a small part has a university education 5 people (4\%).

In this study, the sex of chili farmers was 135 men (100\%). The respondents' average length of farming is 10.5 years. Most of the respondents who have been farming curly red chilies for 11-20 years are 84 people (62\%), and a small proportion 21 years old, only 2 people (2\%).

Table 2 - Consumer Characteristics

\begin{tabular}{|c|c|c|}
\hline Information & Number of people & Percentage, \% \\
\hline \multicolumn{3}{|c|}{ Age (year) } \\
\hline $20-30$ & 9 & 18 \\
\hline $31-40$ & 15 & 30 \\
\hline $41-50$ & 19 & 38 \\
\hline $51-60$ & 7 & 14 \\
\hline Total & 50 & 100 \\
\hline \multicolumn{3}{|c|}{ Gender } \\
\hline Male & 17 & 34 \\
\hline Female & 33 & 66 \\
\hline Total & 50 & 100 \\
\hline \multicolumn{3}{|c|}{ Education } \\
\hline Elementary & 8 & 16 \\
\hline SMP & 15 & 30 \\
\hline SMA & 15 & 30 \\
\hline Universities & 12 & 24 \\
\hline Total & 50 & 100 \\
\hline \multicolumn{3}{|c|}{ Occupations of } \\
\hline Housewives & 29 & 58 \\
\hline Civil Servants & 10 & 20 \\
\hline Private Employees & 6 & 12 \\
\hline Entrepreneur & 5 & 10 \\
\hline Quantity & 50 & 100 \\
\hline
\end{tabular}


The average age of final consumer respondents is 38.3 years, most of which are between 41-50 years of age, as many as 19 people or 38\%, and a small proportion aged 5160 years as many as 7 people or $14 \%$. The sex of most of the final consumers in the research location in the subdistricts of Pakis, Dukun, and Srumbung were 33 women or $66 \%$ and 17 men or $34 \%$.

The education of most of the final consumers in the sub-districts of Pakis, Dukun, and Srumbung are mostly 15 people (Junior High School) or 30\%, and a small portion 12 people or $24 \%$ have tertiary education. The occupations of most of the final consumers in the subdistricts of Pakis, Dukun, and Srumbung are primarily housewives, 29 people or $58 \%$, and a small proportion is self-employed 5 people or $10 \%$.

The results of the regression analysis of the variables that affect the demand for curly red chili in Magelang Regency are described in Table 3 as follows:

Table 3 - Regression Analysis of Variables Affecting Curly Red Chili Supply in Magelang Regency

\begin{tabular}{|c|c|c|c|c|c|}
\hline Estimating & Regression Coefficient & Sig t & Sig F & Tolerance & VIF \\
\hline Constant & 0,101 & & 0,000 & & \\
\hline Production Cost & 1,101 & 0,000 & & 0,993 & 1,007 \\
\hline Harvested area & $-0,405$ & 0,008 & & 0,976 & 1,024 \\
\hline Price at producer level & 0,017 & 0,000 & & 0,979 & 1,021 \\
\hline$R^{2}$ & 0,987 & & & & \\
\hline Asympt sig (2-tailed) & 0,124 & & & & \\
\hline Durbin Watson (d) & 0,624 & & & \\
\hline
\end{tabular}

Based on the table above, the following equation is obtained:

$$
Y_{1}=0,101+1,101 X_{1}-0,405 X_{2}+0,017 X_{3}
$$

Hypothesis Test:

1. The coefficient of determination (R2). Based on the data presented in Table 3, the value of R-Square (R2) of 0.987 indicates that the independent variables (cost of production, harvested area, and prices at the producer level) can explain the dependent variable (supply red chili curly) by $98.7 \%$. In comparison, another $1.3 \%$ is influenced by other variables not included in the model;

2. Simultaneous Test ( $F$ test). Based on the data described in Table 3 , the significant value of $\mathrm{F}$ is 0.000 , more diminutive than $0.05(5 \%)$. Thus $\mathrm{H} 0$ is rejected, $\mathrm{H} 1$ is accepted. This shows that the independent variables simultaneously significantly affect the supply of curly red chili in the Magelang Regency;

3. Partial Test (t-test):

a. Production Costs. The significant value of $t$ production costs is 0.000 , more diminutive than $0.05(5 \%)$. Thus $\mathrm{H} 0$ is rejected, $\mathrm{H} 1$ is accepted. This shows that production costs significantly affect the supply of curly red chili;

b. Harvested Area. The significant value of the $t$ harvested area is 0.008 , more diminutive than $0.05(5 \%)$. Thus $\mathrm{HO}$ is rejected, $\mathrm{H} 1$ is accepted. This shows that the harvested area has a significant effect on the supply of red chilies;

c. Prices at the Producer Level. The significant value of the t price of curly red chili price at the producer level is 0.000 , which is smaller than $0.05(5 \%)$. Thus $\mathrm{H} 0$ is rejected, $\mathrm{H} 1$ is accepted. This shows that the price of red chilies at the producer level significantly affects the supply of red chilies.

This study indicates that the variables of curly red chili prices, production costs, and harvested area have a significant effect on the supply of curly red chilies. These three variables together significantly affect the supply of curly red chilies. This is stated in the microeconomics book, the determinants of supply consist of prices of other goods, production costs, technological changes, and forecasts (Amalia, 2012); this is in line with Ariyani's research (2016) research in Purworejo states that red chili production has an effect on significantly to the supply of red chili because with the increase in the production of red chili it will increase the supply of red chili. 
The results of this study are in line with Laksana's research (2018) which states that the variables of the harvested area and red chili prices at the producer level have a significant effect on the amount of supply or the amount of red chili production in Indonesia. This means that this statement is following the law of supply, which states that the higher the price of an item in the previous year, the higher the production of goods will be, whereas on the contrary, if the price of an item in the previous year decreases, the production of that item will decrease.

Analysis of the Factors Affecting the Demand for Curly Red Chili. Results of the regression analysis of the variables affecting the demand for curly red chili in Magelang Regency are described in Table 4 as follows.

Table 4 - Regression Analysis of Variables Affecting Curly Red Chili Demand in Magelang Regency

\begin{tabular}{|c|c|c|c|c|c|}
\hline Estimating & Regression Coefficient & Sig t & Sig F & Tolerance & VIF \\
\hline Constant & 4,859 & & 0,000 & & \\
\hline Price of chili in consumers & $-1,799$ & 0,007 & & 0,924 & 1,082 \\
\hline Prices of other goods & 0,001 & 0,577 & & 0,921 & 1,086 \\
\hline Revenue & 0,254 & 0,039 & & 0,991 & 1,009 \\
\hline $\mathrm{R}^{2}$ & 0,667 & & & & \\
\hline Asympt Sig (2-tailed) & 0,571 & & & & \\
\hline Durbin Watson (d) & 1,265 & & & & \\
\hline
\end{tabular}

Based on the table above, the following equation is obtained:

$$
Y_{2}=4,859-1,799 X_{1}-0,001 X_{2}+0,254 X_{3}
$$

Hypothesis Test:

1. The coefficient of determination (R2). Based on the data presented in Table 4, the value of R-Square (R2) of 0.667 indicates that the independent variable (red chili prices rising in the consumer, the price of other goods, and consumer incomes can explain the dependent variable (request red curly chili) by $67 \%$. In comparison, another $33 \%$ is influenced by other variables not included in the model;

2. Simultaneous Test (F test). Based on the data described in Table 4, the significant value of $\mathrm{F}$ is 0.000 , more diminutive than $0.05(5 \%)$. Thus $\mathrm{H} 0$ is rejected, $\mathrm{H} 1$ is accepted. This shows that the independent variables simultaneously significantly affect the demand for curly red chili in Magelang Regency;

3. Partial Test (t-test):

a. The price of urly red chili in consumers. The significant value of $t$ The price of curly red chili in consumers is 0.007 , more diminutive than $0.05(5 \%)$. Thus $\mathrm{H} 0$ is rejected, $\mathrm{H} 1$ is accepted. This shows that the price of curly red chili in consumers significantly affects the demand for curly red chili;

b. Price of other goods (large red chili). The significant value of t price of other goods is 0.577 , which is greater than $0.05(5 \%)$. Thus $\mathrm{HO}$ is accepted, $\mathrm{H} 1$ is rejected. This shows that the prices of other goods have no significant effect on the demand for red chilies;

c. Income. The significant value of $t$ income is 0.039 , which is smaller than $0.05(5 \%)$. Thus $\mathrm{H} 0$ is rejected, $\mathrm{H} 1$ is accepted. This shows that the price of curly red chili at the producer level significantly affects the demand for curly red chili.

The demand for curly red chili in Magelang Regency fluctuates every year. In this study, the demand for curly red chili is seen in the consumption data of curly red chili in the Magelang Regency. The decrease and increase in consumption of curly red chili are thought to be influenced by several factors, including the price of curly red chili at the consumer level, the price of large red chilies (other goods), consumer income. The results showed that these three variables together had a significant effect on the demand for curly red chili. This is in line with research by Dewi (2009) in her research which states that the variable prices of curly red chilies and large red chilies as complementary goods have a significant effect on the demand for red chilies in Surakarta City.

These two commodities have the same taste and color so that they are still in great 
demand by consumers. If the price of curly red chili goes up, big red chili as a complementary product will also rise. Following the law of demand states that the lower the commodity's price, the greater the quantity demanded that commodity and vice versa. So, if the price of curly red chili increases, the demand for curly red chili will decrease so that consumers will reduce the consumption of curly red chilies and switch to large red chilies or other substitute goods at lower prices and have the same benefits.

Laksana (2018) research states that red chili is an inferior good for people who have high incomes. The lowest consumption of red chili is in the household sector, while the industrial sector consumes the reddest chili. This means that the higher a person's income, the higher the purchasing power; rather than buying red chili, household residents prefer chili sauce produced by the factory industry.

Based on the research results, the price of curly red chili has a negative regression coefficient value. This sign can be interpreted if the price of curly red chili increases, the number of requests for curly red chili will decrease. This is related to the function of curly red chili as a cooking spice. If the price of curly red chili soars, the demand for curly red chili will decrease to meet the needs of cooking spices.

The same result is also shown in the price of other goods (big red chili), which has a negative regression coefficient value. It can be interpreted that if the price of sizeable red chili increases, the demand for curly red chili will decrease. The partial test results showed that the price of other goods (big red chili) did not affect the demand for curly red chili. This happens because curly red chili is used as a cooking ingredient that homemakers always need daily. Even though there are fluctuations in price ups and downs, consumption will remain stable following the increase in population.

Analysis of the elasticity of supply and demand for curly red chilies. The curly red chilies results of the calculation of the elasticity of prices of curly red chilies show that the elasticity value is $38.15>1$, so it can be concluded that the price of curly red chilies is elastic. This means that every $1 \%$ change in the red chili price variable will change the supply of curly red chili by more than $38.15 \%$.

The calculation of production cost elasticity shows an elasticity value of $0>1$, so it can be concluded that production costs are elastic. This means that every $1 \%$ change in the production cost variable will increase the supply of red chili by $0 \%$.

Based on the elasticity of production costs calculation, the elasticity value is $2.12>1$, so it can be concluded that the harvested area is elastic. Every $1 \%$ change in the harvested area variable will result in changes in the supply of red chili to an increase of $2.12 \%$.

The results obtained on the elasticity of supply are the variable price of curly red chili at the producer level, production costs, and harvested area are elastic. This is because the harvest's addition or reduction can be determined from the price at the producer level in the previous year. If the previous year's price of chili were high, the producer would increase their production that year. If the price is low, the producer will reduce the amount of production. So it is these elastic changes that cause chili prices to fluctuate significantly. The size of the elasticity of supply to price changes is influenced by several things, including Changes in production costs and the period of the production process (Sukirno, 2002)

Results of the calculation of the elasticity of the price of red chili at the consumer level show an elasticity value of $0.007>1$. It can be concluded that the price of curly chili is elastic. This means that every $1 \%$ change in the harvested area variable will change the supply of curly red chili to increase by $0.007 \%$.

Based on the calculation of the elasticity of the price of large red chili, it shows an elasticity value of $11.99>1$, and it can be concluded that sizeable red chili is elastic. This means that every $1 \%$ change in the significant red chili variable will result in an $11.99 \%$ increase in the supply of red chili.

Based on the calculation of the elasticity of consumer income shows an elasticity value of $0.06>1$, it can be concluded that consumer income is elastic. Every $1 \%$ change in consumer income variables will result in changes in consumer income supply, increasing by $0.06 \%$. 
The result obtained from the elasticity of demand is that the price variable at the consumer level is elastic. This is because the size of the demand for curly red chili occurs due to changes in the price of the goods themselves. If the price of curly red chili goes down, the demand for curly red chili will increase. If the price of curly red chili goes up, the demand for curly red chili will decrease slightly. So, the increasing demand for curly red chili causes prices to be higher and results in inflation.

Balance of Supply and Demand for Curly Chili in Magelang Regency. The balance of supply and demand balance of supply and demand will be analyzed using the theory of balance analysis cobweb. This analysis begins by forming a supply and demand equation with a linear regression of the price of curly red chili with supply and demand:

Table 5 - Linear Regression Offers and Demand Balance

\begin{tabular}{|c|c|c|c|c|}
\hline Regression Model & Constant & Regression Coefficients & T & Sig \\
\hline Quote & 0,101 & 0,900 & 7,810 & 0,000 \\
\hline Demand & 4,859 & 2,405 & 2,020 & 0,049 \\
\hline
\end{tabular}

According to Table 5 above, the equations for the demand function and supply function are as follows:

$$
\begin{gathered}
Q_{s t}=0,101+0,900 P_{r t} \\
Q_{d t}=4,859+2,405 P_{r t-1}
\end{gathered}
$$

Based on the assumption of Cobweb equilibrium, the equilibrium model is obtained as follows:

$$
\begin{gathered}
Q_{s t}=Q_{d t} \\
0,101+0,900 P_{r t}=4,859+2,405 P_{r t-1} \\
0,900 P_{r t}+2,405 P_{r t-1}=4,859+0,101 \\
0,900 P_{r t}+2,405 P_{r t-1}=4,96
\end{gathered}
$$

Then we get:

$$
\begin{aligned}
& \delta=2,405 \\
& \beta=0,900 \\
& \alpha+\gamma=4,96
\end{aligned}
$$

Then enter the formula:

$$
\begin{gathered}
y^{t+1}+a y_{t}=c \\
A b^{t+1}+\alpha A b^{t}=c \\
A b^{t+1}+\alpha A b^{t}=0 \\
A b^{t} \cdot b+\alpha A b^{t}=0 \\
b+\alpha=0 \\
b=-\frac{\delta}{\beta}
\end{gathered}
$$

So that the following results are obtained:

$$
\begin{gathered}
b=-\frac{\delta}{\beta} \\
b=-\frac{2,405}{0,900} \\
b=-2,67 \\
b=-2,67<1 \\
b=<1
\end{gathered}
$$


From the supply and demand functions, the following equation model is obtained:

$$
\begin{gathered}
Q_{s t}=0,101+0,900 P_{r t} \\
Q_{d t}=4,859+2,405 P_{r t-1}
\end{gathered}
$$

Based on the Cobweb model, the following results are obtained:

$$
\begin{gathered}
b=-2,67<1 \\
b=<1
\end{gathered}
$$

Effect the supply and demand price for curly red chili in Magelang Regency is convergent or towards the equilibrium point. Meaning that the effect of supply price is too significant, so that the increase in production as a reaction to the increase in price is excessive, so farmers increase the amount of their production by increasing their land area. This cycle is included in case II in Figure 1.

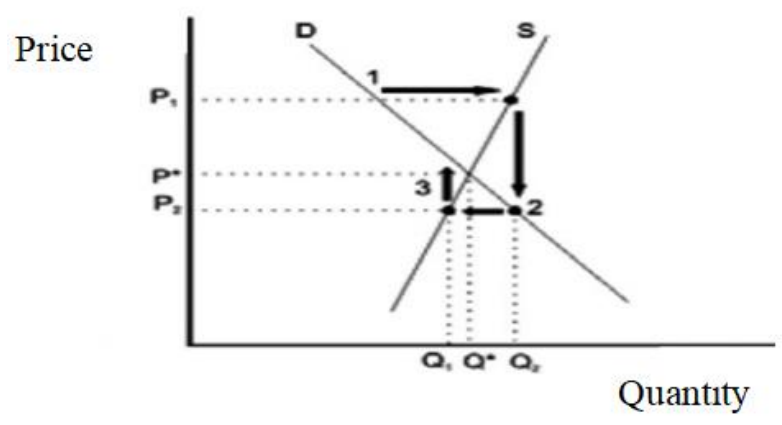

Figure 1 - Cobweb's theory

In case II, the equilibrium price is initially at the equilibrium price and the equilibrium quantity of output, then the price increases to the first price, the production is increased but not as much as in the case I. This causes the price to decrease but not as much as the price decrease in case I. The supply curve in case I more elastic than the supply curve in case II, so that price fluctuations are more significant in case I (Mubyarto, 1989).

\section{CONCLUSION}

From the results of research on supply and demand for red chili in Magelang Regency, the following conclusions are obtained:

1. Based on the analysis of the simultaneous test ( $F$ test), the results showed that simultaneously the independent variables calculated in the model, namely production costs, harvested area, and prices at the producer level, had a significant effect on supply. The regression results on partial hypothesis testing (t-test) show that all independent variables, including production costs (X1), land area (X2), and producer level prices (X3), have a significant effect on the supply of curly red chili in Magelang Regency;

2. Based on the analysis of the simultaneous test ( $F$ test), the results show that simultaneously the independent variables calculated in the model, namely prices at the consumer level, prices of other goods, and income, have a significant effect on demand. The regression results in partial hypothesis testing (t test) show that the independent variables which include prices at the consumer level (X1), and income (X2) have a significant effect on the demand for red chilies in Magelang Regency, while the price variable for other goods (X2) does not significant effect on the demand for curly red chili in Magelang Regency.

3 . The results of the elasticity of supply consisting of the elasticity of production costs showed that it was elastic, the elasticity of harvested area showed inelasticity, and the price elasticity of curly red chili at the producer level was inelastic. The elasticity of demand, which 
consists of the price elasticity of curly red chili at the consumer level, is inelastic, the price elasticity of other goods (large red chili) is elastic, and the elasticity of consumer income is elastic inelastic;

4. Based on the Cobweb analysis, the value of $b$ (beta) $=-2.67<1$, it can be concluded that the effect of price on supply and demand for curly red chili in Magelang Regency is convergent or close to the equilibrium point.

\section{SUGGESTIONS}

The results showed that consumer income had a significant effect on demand. This causes demand to continue to grow every year, so it must be supported by an adequate supply of curly red chilies. The government is expected to be able to control the price of curly red chili so that when the harvest season, the price of curly red chili is not to the detriment of farmers, and the government is more active in socializing government policies regarding the price of minimum curly red chili so that farmers are always interested in growing curly red chilies.

It is hoped that farmers will always be interested in growing curly red chilies, improve their skills in managing curly red chilies, and be able to apply the technology recommended by the Department of Agriculture so that the productivity of curly red chilies can be increased in order to increase local production and reduce inflation.

\section{REFERENCES}

1. Amalia, L and Asfia. 2017. Revised edition of Microeconomics. PT Refika Aditama, Bandung.

2. Blocher, Kung, Gary, Thomas. 2007. Cost Management: Strategic Emphasis. Salemba four: Jakarta.

3. Boediono. 1993. Macroeconomics. Synopsis Series Introduction to Economics No. 2. BPFE, Yogyakarta.

4. BPS Magelang Regency. 2017. Magelang Regency in Figures 2017. Magelang.

5. BPS Magelang Regency. 2018. Magelang Regency in Figures for 2018. Magelang.

6. BPS Magelang Regency. 2019. Magelang Regency in Figures for 2019. Magelang.

7. Chairia. 2013. Analysis of Demand and Demand for Red Chili in North Sumatra Province. University of Northern Sumatra. Medan City, North Sumatra.

8. Ghozali, I. 2011. Application of Multivariate Analysis with IBM Programs. SPSS 19. 5th Ed. Diponegoro University, Semarang.

9. Hadi, Rahma. 2017. Factors Affecting Demand for Curly Red Chili in Households in Banyumanik District, Semarang City. Diponegoro University. Semarang

10. Hanky, and Thomas. 2012. Management System of Carrot Vegetable (Daucus carota L) Marketing Institute in Rurukan Village, East Tomohon District. Thesis. Postgraduate Program at Sam Ratulangi University., Manado.

11. Hapsari, SD. 2013. Evaluation of Production Cost Control Effectiveness and Production Cost Efficiency (Case Study at PT. XYZ). JAMS -Journal of Management Studies Vol. 2, No.1, May 2013.

12. Kotler, P. 2008. Marketing Management. Erlangga Publisher. Jakarta.

13. Laksana, B. 2018. Analysis of the Balance of Demand and Demand for Red Chili in Indonesia. University of Muhammadiyah Malang. Malang City, East Java.

14. Rahardja, Prathama. Manurung, Mandala. 2006. An Introduction to Microeconomic Theory, Third Edition, Jakarta; Publishing Institute of the Faculty of Economics, University of Indonesia.

15. Sugiyono. 2018. Quantitative, Qualitative and R\&D Research Methods. Alphabet. Bandung.

16. Wahyudi, 2011, Harvesting Chili throughout the Year. PT Agromedia Pustaka. Jakarta.

17. Wahyudi, H and Soepatini. 2018. Analysis of Chili Commodity Price Formation in Surakarta. Muhammadiyah University of Surakarta, Solo. 